\title{
Analysis of Forest Cover Changes Using Landsat Satellite Imagery: A Case Study of the Madhupur Sal Forest in Bangladesh
}

\author{
Mohammad Abdullah Al Faruq*1, Sourovi Zaman*2 and Masato Katoh*1
}

\begin{abstract}
Bangladesh is a poor, partially forested nation located in South Asia. The forests cover an estimated 17.1\% of the land surface area of the nation. Rapid human population expansion has increased wood consumption and resource overexploitation, leading to the degradation of forest reserves. We mapped and analyzed forest cover change for the period 1972-2014 using Landsat satellite images of the Madhupur Sal forest captured in 1972, 1991, 2010, and 2014. This forest is a tropical deciduous stand within the Bangladeshi Tangail Forest Division. Forest cover changes were identified and approximately delineated on remotely sensed images. We applied a supervised classification approach to the satellite images using ERDAS IMAGINE ver.10 software. The mapping and analyses of five land-use classes were performed with ArcGIS ver.10 software. Thus, we analyzed the trends in forest cover changes over 42 years. The area under natural forest cover was progressively reduced by 7079.4 ha through anthropogenic activities during the period 1972-2010. However, the natural forest area increased by 202.4 ha between 2010 and 2014 due to the implementation of a revegetation program involving local community groups that was initiated by the national forest department. Our maps are very relevant to forest conservation initiatives and will enable a long-term, integrated approach to forest revegetation operated by the forest department in association with local communities.
\end{abstract}

keyword: forest cover, Madhupur, remote sensing, rubber plantation, Sal tree

\section{INTRODUCTION}

Among natural resources, forests are undoubtedly the most important for sustainable development across the globe. They directly influence local atmospheric cycles and contribute enormously to the diverse needs of forest-

Affiliations and addresses of the authors:

${ }^{* 1}$ Forest Measurement and Planning Laboratory, Department of Forest Science, Faculty of Agriculture, Shinshu University 8304, Minamiminowa-vill, Kamiina-Dist., Nagano Prefecture, 399-4598, Japan

*2 Assistant professor, Shahid Akbar Ali Science \& Technology College, Baliadangi, Thakurgaon, Bangladesh

Corresponding author: Mohammad Abdullah Al Faruq Postal Address: Forest Measurement and Planning Laboratory, Department of Forest Science, Agriculture Faculty, Shinshu University 8304, Minamiminowa-vill, Kamiina-Dist., Nagano Prefecture, 399-4598, Japan

Tel: +81-265-77-1642

E-Mail: faruq1010@yahoo.com dependent and forest-independent peoples as well as to socioeconomic development and environmental stability. Unsustainable management of forest resources coupled with increasing population has resulted in dramatic change of forest cover in tropical countries. Here, change is defined as "an alteration in the surface components of the vegetation cover" (Milne, 1999). Detecting forest conditions and monitoring changes in forest structure lead to improved understanding of forest ecosystem services. Forest change detection is important for updating forest-cover maps and for monitoring and managing forest resources because it provides a quantitative analysis of the spatial distribution of forest density. For a comprehensive understanding of changes in tropical forest conditions, change analyses should span at least several decades (Lambin, 1999). Long-term datasets allow managers to draw meaningful inferences from the information at hand.

Temporal remote sensing data which offers an effective way to monitor gradual forest cover and ecosystem changes are used in many parts of the world. Remotely sensed data relating to land use and its changes over time provide crucial information for a range of diverse applications, such as environmental protection, forestry, hydrology, agriculture, and geology, among others. They present current conditions and provide digital data acquisition characteristics. Remote sensing is among the most accurate means of measuring the 
extent and pattern of changes in vegetation cover over a period of time (Miller et al., 1998). It has the potential to provide comprehensive information on diverse criteria for forest management. Data on forest/land-cover changes are required for updating land-cover maps, managing resources effectively, and planning for sustainable development (Alphan, 2003; Muttitanon and Tripathi, 2005). Satellite image quality and availability have greatly improved in recent years. These improvements have enabled progress in image analysis procedures. Although most developed countries have detailed updated information on land use and land cover the dearth of geospatial databases for many developing countries hampers appropriate development planning.

Bangladesh is a densely populated, South Asian nation that is still in the development stage. Poverty and unemployment rates are very high, and disadvantaged people naturally place great pressure on the country's natural resources as they forage for fuel and food. Deforestation is a major issue in a nation where forest resources are of ecological and economic importance. The estimated per capita consumption of timber and fuel wood is only $0.01 \mathrm{~m}^{3}$ and $0.07 \mathrm{~m}^{3}$, and the demand for timber and fuel wood is calculated to be 3.2 and 8.7 million $\mathrm{m}^{3}$, thus giving an estimated deficit of 62 and 60 percent, respectively (IMF, 2005). The forests contribute significantly to the agricultural income of Bangladesh. It contributed about $1.76 \%$ of the country's GDP and $16.77 \%$ of the agriculture income in 2012-13 (BBS, 2014). A total forest cover of $25 \%$ is required for the country to maintain ecological balance and environmental stability. Bangladesh has approximately $2.52 \times 10^{6}$ ha of forested land, accounting for $c a .17 .1 \%$ of the national land area (BFD, 2010). In the past 30 years, the area of forest has rapidly decreased. The average annual rate of deforestation is $3-4 \%$ (Rasheed, 2008), which can be explained by the high rate of human population growth, commercial land use, the high demand for fuel wood, and extremely heavy use of natural resources (Alam et al. 2008). However, the poor budgetary practices of the national government do not provide extensive information on national forest resources. The scarcity of essential data delays programs aimed at mitigating the effects of deforestation. The development of strategies for estimating forest resources is therefore among the urgent issues required for sustainable forestry in Bangladesh.

Among the wooded tracts in Bangladesh, the Sal forest is crucial to the development of appropriate management methods for the country. This vegetation, which is dominated by the Sal tree (Shorea robusta), is the third largest forest ecosystem in Bangladesh (BFD, 2011); the stands are classified as tropical, moist, deciduous forest (UNEP, 2002). Sal forests occupy $c a$. 0.12 million ha, representing $4.7 \%$ of the total wooded area of Bangladesh (GOB, 2010). Most of the Sal forest is located in the greater Mymensingh and Tangail districts, also known as Madhupur Grath (Rahman, 2003). The Madhupur Sal forest is considered precious; it is the only forest located in the flood-free central part of the country. The Madhupur Sal forest has functioned for centuries as the homeland for ethnic communities such as the Garo and Koch (Ahmed, 2008). Thousands of people have become directly and indirectly dependent on the forest, placing it under severe pressure in recent decades through illegal logging, clearing for agriculture and industrialization, and the provision of livelihoods for the poor living around the forest (BFD, 2004). These pressures have caused significant changes to the forest and its associated resources. Encroachment and tree removal have significantly degraded forest ecological functions (Muhammed et. al., 2008). Such overexploitation, combined with inappropriate management, has made forest resource use unsustainable (Iftekhar, 2006).

The goal of sustainable forest management is to provide a steady flow of resources and income while preserving vegetation cover, biodiversity, and ecosystem integrity (Webb and Sah, 2003). In the early 1990s, the Bangladesh Forest Department and many NGOs participated in several social forestry programs to mitigate the deforestation (Salam and Noguchi, 2006; Alam et al., 2010). The programs contributed importantly by revegetating occupied forest lands with fast-growing plant species, but much less attention was given to sustainable conservation of the Sal forest. Sustainable forest management will require an understanding of the natural characteristics, distribution, quality, suitability, and limitations of the stands in relation to provision of resources to the human population. Most importantly, information on past and present land cover in the area is crucial for sustainable management (Chaurasia et al., 1996). Few literature sources describe the status of the Sal Forest or changes in its canopy cover over time, although a range of reports provide information on soil quality, biodiversity, social forestry, and agro-forestry. In the face of rapid deforestation and the dearth of information on changes in vegetation cover, we focused on calculations of forestcover change by using remote sensing technology to classify digital images.

We attempted to map land use in the Madhupur Sal forest over 42 years (1972-2014), focusing primarily on estimation of the rate of forest-cover change. The data that emerged should facilitate dynamic forest management planning. Our work also contributed to the development of remote sensing technology for developing countries, such as Bangladesh, where data gathered by satellite imagery will be especially valuable, as information gathering at ground level is inherently difficult.

\section{MATERIALS AND METHODS}

Study Area

Forest is a complex ecosystem consisting mainly of trees that buffer the earth and support a myriad of life forms. In Bangladesh, forest land spanning more than 0.5 hectares with trees higher than 5 meters and a canopy cover of more than 10 percent, or trees able to reach these thresholds in situ. It does not include land that is predominantly under agricultural or urban land use (FRA, 2015). The Madhupur deciduous Sal forest $\left(24^{\circ} 32^{\prime}-24^{\circ} 47^{\prime} \mathrm{N}, 8^{\circ} 59^{\prime}-90^{\circ} 11^{\prime} \mathrm{E}\right)$ covers an area of $c a$. 31,222 ha. It is located in the northeastern section of the Tangail Forest Division; a small segment runs along the boundary of the Mymensingh Forest Division (Fig. 1). 


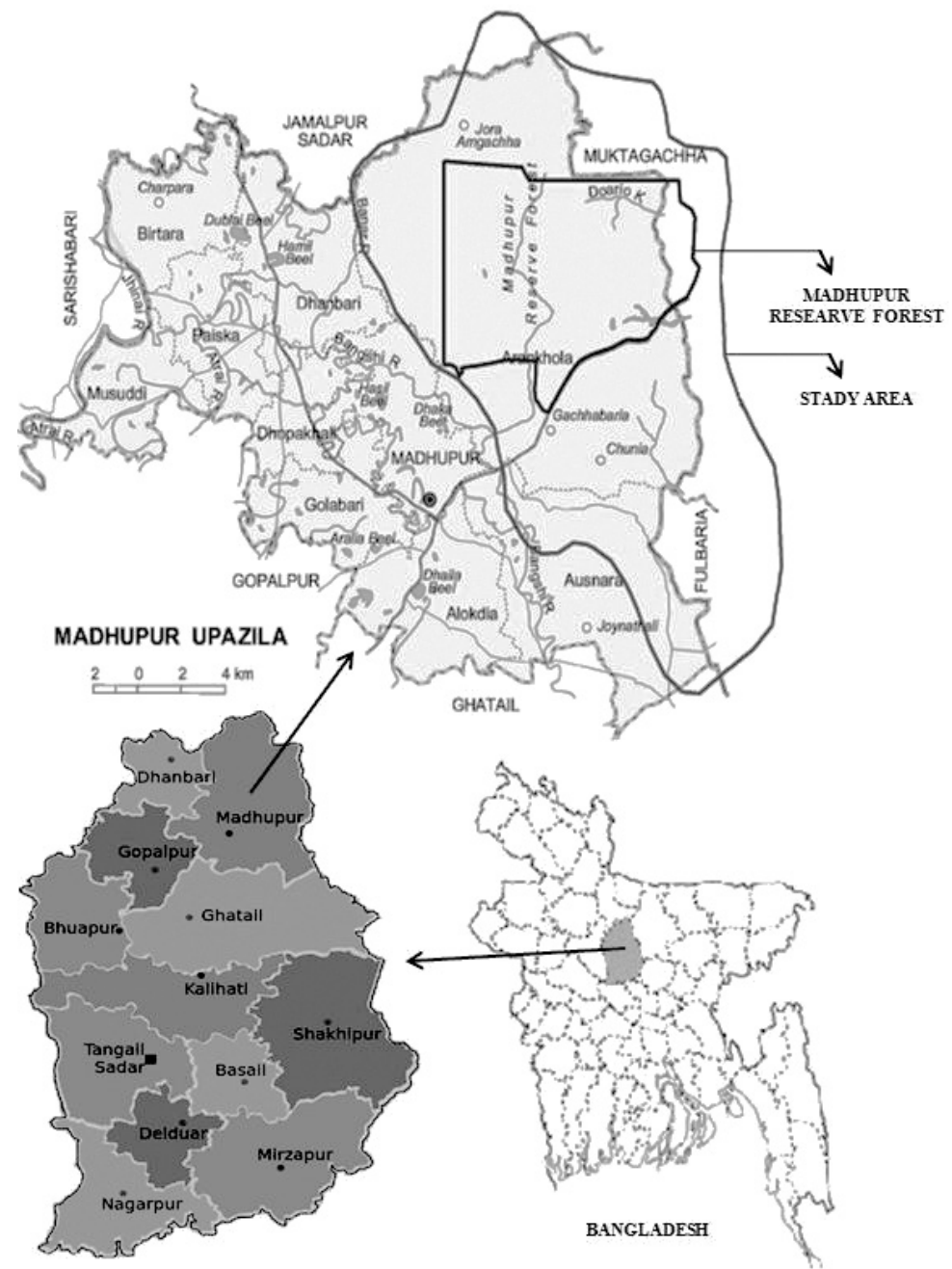

Fig. 1 Location of the study area in Madhupur, Bangladesh

The study site was selected because of the anthropogenic threats facing this stand. Land use in Bangladesh is changing rapidly, and new developments affect the area significantly. The Madhupur Sal stand is the only forest in central Bangladesh. Thousands of ethnic and non-ethnic people depend on its products. The forest is under strong pressure from illegal logging and land encroachment, both of which degrade forest resources. A major portion of the forested area ( $c a .8,499$ ha) has been given "reserve forest" status. The designation was announced in a gazette in 1982, when the reserve was renamed the "Madhupur National Park." Reducing and perhaps reversing the rapid degradation of the stand requires acquisition of robust data on the rates and trends of degradation. Conservation and preservation programs will be enabled by such reliable information.

The forest is located $c a .20 \mathrm{~m}$ above mean sea level. The mean annual rainfall is 2,000-2,300 $\mathrm{mm}$, and annual mean temperature is $26.3^{\circ} \mathrm{C}$ (Rahman, 2003). The forest is divided into four administrative ranges: Jatyo Uddyan, Dokhola, Aronkhola, and Madhupur. The Madhupur Sal forest area, commonly known as the Madhupur Garh, is on a tract of land ca. 1-2 $\mathrm{m}$ higher than the surrounding plains. The ridges, known locally as Chala, are covered with forest formations and are not continuous. The forest is dense in some parts and sparse in others; scrub jungle also occurs on the ridges. The forest canopy height varies between $10 \mathrm{~m}$ and $30 \mathrm{~m}$. The dominant species $(80-100 \%$ of trees) is the commercially profitable Sal tree (Shorea robusta), which dominates the upper canopy. It is associated with Ajuli (Dillenia jpentagyna), Amlaki (Phyllanthus emblica), Koroi (Albizia procera), Terminalia sp, and Sonalu (Cassia fistula), among other taxa. The understory includes Bambusa sp., Alsophila sp., and several ferns and epiphytes (Feeroz and Islam, 2000).

\section{Datasets}

We used four multi-temporal satellite images (Landsat MSS 1972, Landsat TM 1991, Landsat TM 2010, and Landsat OLI 2014) to classify land use and to evaluate forest-cover changes in the Madhupur Sal forest area. The images selected spanned temporal changes at intervals of $c a$. two decades prior to the start of a revegetation program in 2009. The images were collected from the Global Land Cover Facility (GLCF) and USGS Global Visualization Viewer (GLCF, 2014) (Table 1). The Landsat Multispectral Scanner (MSS) had four spectral bands with a spatial resolution of $60 \mathrm{~m}$. The Landsat Thematic Mapper (TM) had seven spectral bands with a spatial resolution of $30 \mathrm{~m}$ (except band 6, which had 120-m resolution). The Landsat Operational Land Imager (OLI) had nine spectral bands with a spatial resolution of $30 \mathrm{~m}$ (except for band 8 , which had a 15-m 
Table 1 List of satellite images selected.

\begin{tabular}{cccc}
\hline Satellite data & Date & $\begin{array}{c}\text { Spatial } \\
\text { resolution }\end{array}$ & Bands \\
\hline MSS (WRS-1, Path 148, Row 43) & $23 / 11 / 1972$ & $60 \mathrm{~m}$ & $4,3,2$ (NIR, R, G) \\
TM (WRS-2, Path 137, Row 43) & $26 / 11 / 1991$ & $30 \mathrm{~m}$ & $4,3,2$ (NIR, R, G) \\
TM (WRS-2, Path 137, Row 43) & $30 / 1 / 2010$ & $30 \mathrm{~m}$ & $4,3,2$ (NIR, R, G) \\
OLI (WRS-2, Path 137, Row 43) & $30 / 3 / 2014$ & $30 \mathrm{~m}$ & $5,4,3$ (NIR, R, G) \\
\hline
\end{tabular}

NIR, near infrared: R, red; G, green. MSS, Landsat Multispectral Scanner; TM, Landsat Thematic Mapper; OLI, Landsat Operational Land Imager

Table 2 Major specifications of MSS, TM, and OLI

\begin{tabular}{cccccc}
\hline \multicolumn{2}{c}{ MSS } & \multicolumn{2}{c}{ TM } & \multicolumn{2}{c}{ OLI } \\
\hline $\begin{array}{c}\text { Observed } \\
\text { band }\end{array}$ & $\begin{array}{c}\text { Wave range } \\
(\mu \mathrm{m})\end{array}$ & $\begin{array}{c}\text { Observed } \\
\text { band }\end{array}$ & $\begin{array}{c}\text { Wave range } \\
(\mu \mathrm{m})\end{array}$ & $\begin{array}{c}\text { Observed } \\
\text { band }\end{array}$ & $\begin{array}{c}\text { Wave range } \\
(\mu \mathrm{m})\end{array}$ \\
\hline Band 4 & 0.5 to 0.6 & Band 2 & 0.52 to 0.60 & Band 3 & 0.53 to 0.59 \\
Band 5 & 0.6 to 0.7 & Band 3 & 0.63 to 0.69 & Band 4 & 0.64 to 0.67 \\
Band 6 & 0.7 to 0.8 & Band 4 & 0.75 to 0.90 & Band 5 & 0.85 to 0.88 \\
\hline
\end{tabular}

MSS, Landsat Multispectral Scanner; TM, Landsat Thematic Mapper; OLI, Landsat Operational Land Imager

spatial resolution). Table 2 lists the band specifications of sensors used in the study (USGS, 2014). All of the images were acquired between November and March, during the dry season. The images were clear and cloud free, and had moderate color contrast for land-use mapping and change detection. Our application of satellite images to land-cover mapping and change detection was supported by a number of national and international studies: Naithani (1990), Rosenholm (1993), Quadir et al. (1998), Islam et al. (2006), Islam (2006), Zaman and Katoh (2011), Nath (2014).

Data processing and analysis

The flow chart in Fig. 2 depicts the sequence used in our research. Multi-temporal sets of remote sensing data were used to categorize land-use classes. The image processing software package ERDAS IMAGINE ver.10 (ERDAS, Inc., Atlanta, GA, USA) and the vector data manipulation software ArcGIS ver.10 (ESRI, Redlands, CA, USA) were used to process, analyze, and integrate spatial data. To make the images comparable, the digital image data were first transformed to a uniform ground coordinate system. Geometric correction was required to avoid geometric distortions; thus, we established an image coordinate system relationship. We first performed image rectification on the Landsat TM 2010 image using the World Geodetic System (WGS) 1984 datum, zone 46 north, which is derived from the Universal Transverse Mercator (UTM) coordinate system. We used 15 well-distributed ground control points (GCPs). Finally, Landsat TM 2010 was rectified to 0.25 pixels $(7.5 \mathrm{~m})$ using the nearest-neighborhood method with root square mean errors. Landsat MSS 1972, Landsat TM 1991, and Landsat OLI 2014 images were subsequently rectified to Landsat TM 2010 using image-to-image rectification, and resampled to $30-\mathrm{m}$ pixels using the nearest-neighborhood method. We subsequently generated a false color composite combination of infrared, red, and green to facilitate vegetation recognition; chlorophyll in plants strongly reflects the near infrared. We then generated subset, and selected

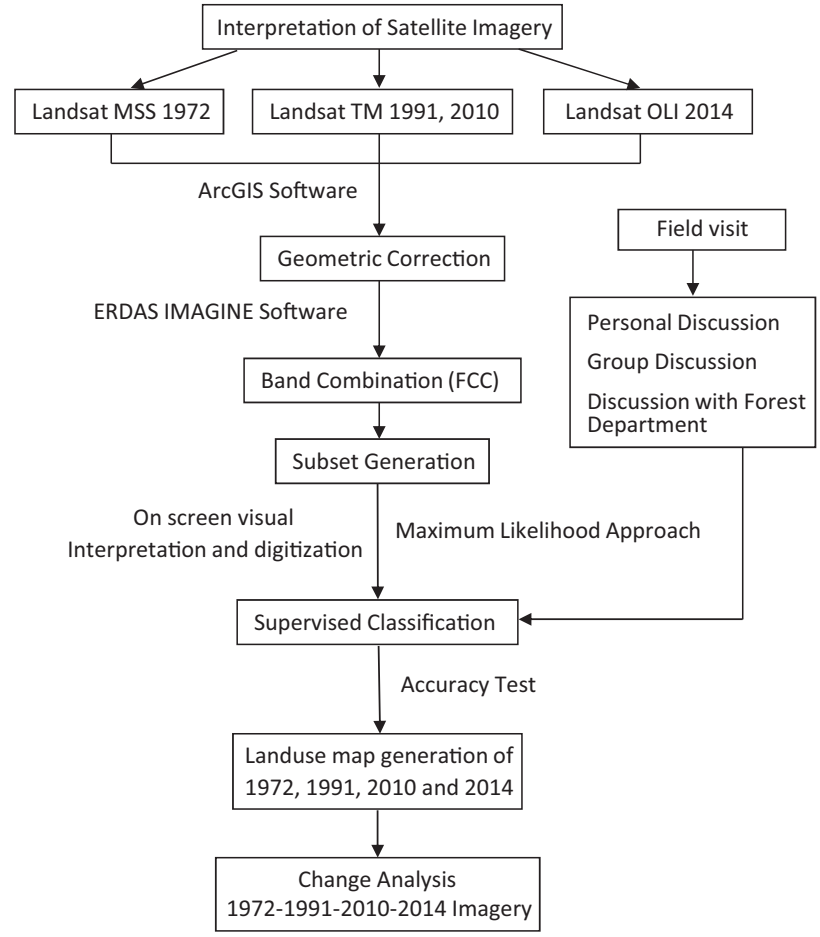

Fig. 2 Flow chart depicting the sequence of procedures used in the study

the areas of interest at the study site.

Finally, we categorized the images using the maximum likelihood classification (MLC) technique of supervised classification approaches; five land-use classes were identified: natural forest, rubber plantation, woodlot plantation, water bodies, and settlements/croplands/other uses. The supervised classification procedure requires training areas for each of the classes identified. These training areas were used to define spectral reflectance patterns/signatures of each land-use category. The signatures were then used by classifiers to group the pixels into a selected category consistent with the spectral patterns. 
Table 3 Interpretation key for MSS, TM, and OLI images.

\begin{tabular}{|c|c|c|c|}
\hline $\begin{array}{l}\text { Landsat } \\
\text { imagery }\end{array}$ & Feature & Physical characteristics & Feature color in the images \\
\hline MSS & $\begin{array}{l}\text { Natural forest } \\
\text { Rubber plantation } \\
\text { Woodlot plantation } \\
\text { Water bodies } \\
\text { Settlements/croplands/other uses }\end{array}$ & $\begin{array}{l}\text { Tropical moist deciduous forest } \\
\text { Rubber tree plantation } \\
\text { Native/exotic tree species } \\
\text { River, pond, canal } \\
\text { Crop/bare land, rural houses with } \\
\text { homestead gardens, roads etc. }\end{array}$ & $\begin{array}{l}\text { Dark red with smooth texture } \\
- \\
- \\
\text { Dark green with smooth texture } \\
\text { Light green, whitish, cyan with medium } \\
\text { texture }\end{array}$ \\
\hline $\mathrm{TM}$ & $\begin{array}{l}\text { Natural forest } \\
\text { Rubber plantation } \\
\text { Woodlot plantation } \\
\text { Water bodies } \\
\text { Settlements/croplands/other uses }\end{array}$ & $\begin{array}{l}\text { Tropical moist deciduous forest } \\
\text { Rubber tree plantation } \\
\text { Native/exotic tree species } \\
\text { River, pond, canal } \\
\text { Crop/bare land, rural houses with } \\
\text { homestead gardens, roads etc. }\end{array}$ & $\begin{array}{l}\text { Dark to pinkish red with smooth texture } \\
\text { Light red with smooth texture } \\
\text { Dark red with medium texture } \\
\text { Dark blue with smooth texture } \\
\text { Light green, whitish, cyan, red with } \\
\text { medium texture }\end{array}$ \\
\hline OLI & $\begin{array}{l}\text { Natural forest } \\
\text { Rubber plantation } \\
\text { Woodlot plantation } \\
\text { Water bodies } \\
\text { Settlements/croplands/other uses }\end{array}$ & $\begin{array}{l}\text { Tropical Moist deciduous forest } \\
\text { Rubber tree plantation } \\
\text { Native/exotic tree species } \\
\text { River, pond, cannels } \\
\text { Crop/bare land, rural houses with } \\
\text { homestead gardens, roads etc. }\end{array}$ & $\begin{array}{l}\text { Pinkish red with smooth texture } \\
\text { Light red with smooth texture } \\
\text { Dark red with medium texture } \\
\text { Dark blue with smooth texture } \\
\text { Whitish, cyan, red with medium texture }\end{array}$ \\
\hline
\end{tabular}

MSS, Landsat Multispectral Scanner; TM, Landsat Thematic Mapper; OLI, Landsat Operational Land Imager

We selected 15 homogeneous training areas for each land-use class and used an interpretation key for classification. The interpretation key was created with the aid of visual analysis of the images using displays of red/green/blue (RGB) combinations. The classification was also supported by reference data and ancillary information. The reference data, which were collected from digital forest-cover maps for 1963, 1977, 1991, 2003, and 2008, together with visual interpretations of the images, were used to validate the classified images. The ancillary information was obtained from the digital land-use map, forest-cover maps, Google Earth (Google Inc., Googleplex, Mountain view, California, USA), and the author's prior knowledge of the study area obtained by visiting the site. A $3 \times 3$ majority filter was finally applied to smooth the classified images. The land use descriptions were as follows:

* Natural forest: Most of the trees in natural forests were indigenous and had recruited naturally. The stands were capable of producing timber or other wood products.

* Rubber plantation: Areas covered with rubber trees (Hevea brasilensis).

* Woodlot plantation: Areas covered with native and exotic timber-producing tree species.

* Water bodies: Rivers, lakes, ponds, irrigation lines, and seasonal standing water.

* Settlements/croplands/other uses: Agricultural lands used to produce human food, and bare land devoid of vegetation, such as sand dunes and exposed soil. Settlements were mostly rural housing with homestead vegetation. Other uses included roads, and an air force live bombing ground.

We produced land-use maps for 1972, 1991, 2010, and 2014. The general land use of an area conveyed information on the overall area-based utilization of both natural and cultural resources.

Accuracy assessment was the next step in image classification. It is very important for interpreting and application of the results. We used this procedure to evaluate the quality of each thematic map from a satellite image. The software we used contained an accuracy assessment tool; overall accuracy and kappa statistics were computed. Finally, using the ERDAS IMAGINE attribute table, we calculated the area statistics (in ha) of each land-use category and then compared different classes of land use among years. Thus, we examined changes in forest cover and other land use within the Madhupur Sal forest at decadal intervals over 42 years (1972-1991-2010-2014). Statistically significant differences were detected using Microsoft Excel 2003 software (Microsoft Corporation, Redmond, WA, USA).

Interpretation key

The criterion set by interpretation elements that we used for identification of an object was termed an interpretation key. The key is a set of guidelines used to assist interpreters in rapid identification of features on a remote sensing image. The six primary elements of visual interpretation were tone (or color), size, shape, texture, shadow, and pattern. We developed an interpretation key for the study years by cross-comparing existing maps of the forest cover and the tonal characteristics of false color composite (FCC) imagery. Tone refers to the relative brightness or color of objects captured in an image. Texture is the frequency of tonal change on the image; it determines the overall visual smoothness or coarseness of an image's features. We interpreted images using ERDAS IMAGINE ver. 10 software, with additional information provided by (i) maps made available by Google Earth, (ii) a land-cover map of the Madhupur Reserve Sal forest, and (ii) site visits (site visits included discussions with Forest Department and local people, as well as the authors' personal examination of the forest). Table 3 lists the land-cover characteristics and interpretative remarks. 


\section{RESULTS}

Land-use classification

The study area was categorized into five land-use classes: natural forest, rubber plantation, woodlot plantation, water bodies, and the "settlements/croplands/other uses." The land use maps for 1972, 1991, 2010, and 2014 are depicted in Fig. 3. Table 4 lists the areas occupied by each land-use category. The settlements/croplands/other uses category

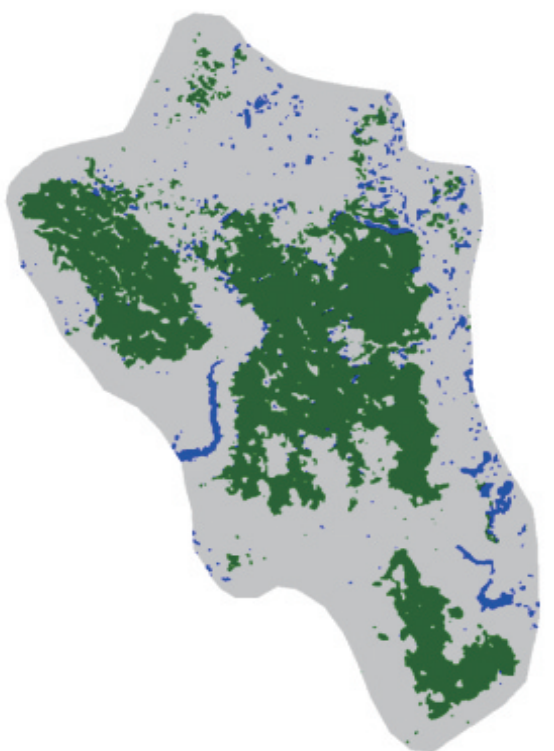

a. 1972

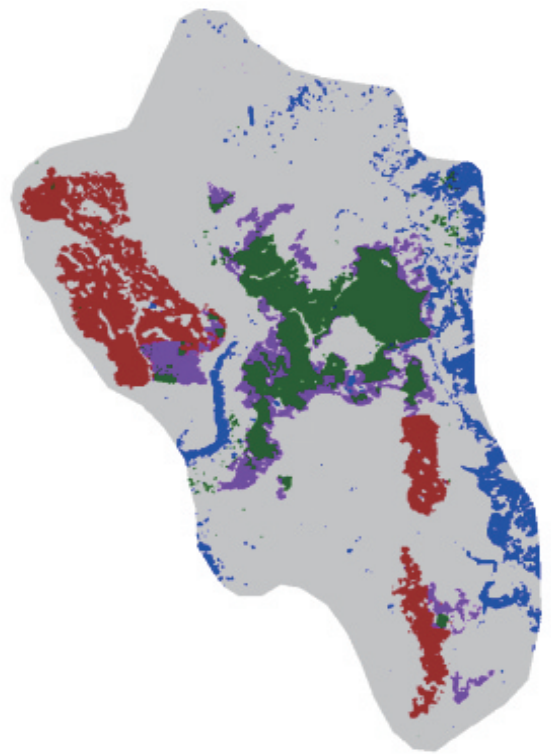

c. 2010

\section{Legend}

Water bodies
Woodlot plantation

Rubber plantation

Natural forest

Settlements/croplands/other uses

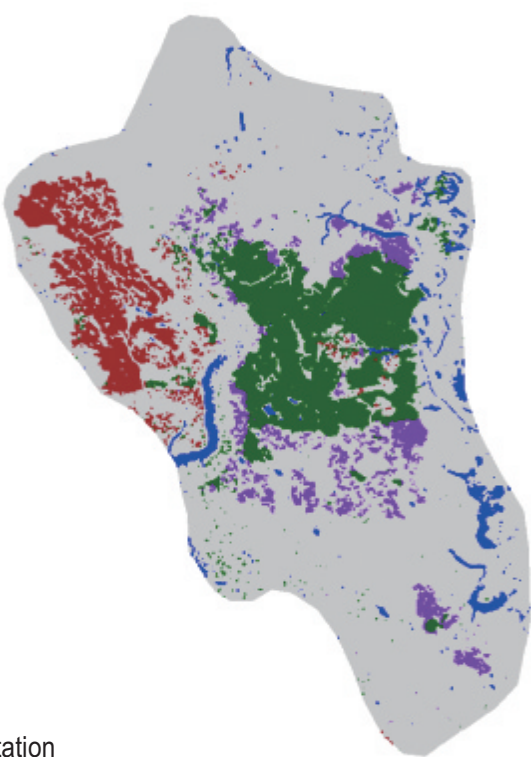

b. 1991

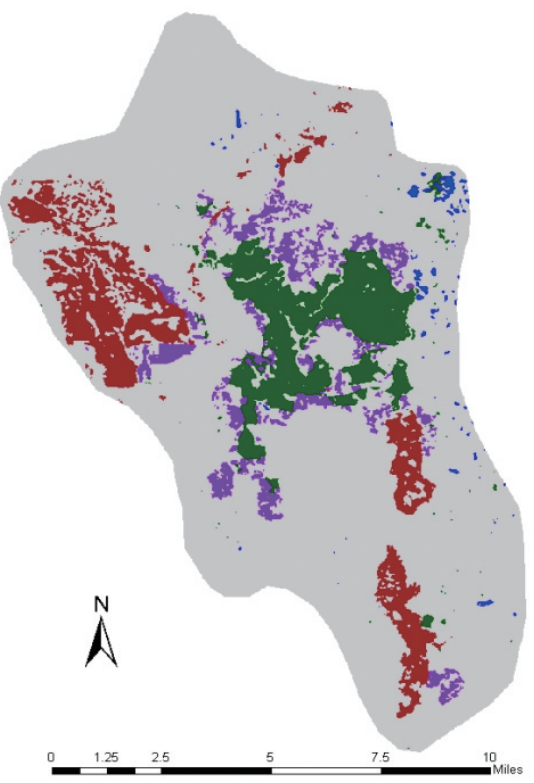

d. 2014

Fig. 3 Classified image maps of the Madhupur Sal Forest area

Table 4 Land areas (ha) and their proportions (\%) of the total calculated from maps of different land uses in the Madhupur Sal forest area

\begin{tabular}{|c|c|c|c|c|c|c|c|c|c|c|c|}
\hline \multirow[t]{2}{*}{ Year } & \multicolumn{2}{|c|}{$\begin{array}{l}\text { Natural } \\
\text { forest }\end{array}$} & \multicolumn{2}{|c|}{$\begin{array}{l}\text { Rubber } \\
\text { plantation }\end{array}$} & \multicolumn{2}{|c|}{$\begin{array}{l}\text { Woodlot } \\
\text { plantation }\end{array}$} & \multicolumn{2}{|c|}{$\begin{array}{l}\text { Water } \\
\text { bodies }\end{array}$} & \multicolumn{2}{|c|}{$\begin{array}{c}\text { Settlements/croplands/ } \\
\text { other uses }\end{array}$} & \multirow{2}{*}{$\begin{array}{l}\text { Total } \\
\text { area }\end{array}$} \\
\hline & (ha) & $\%$ & (ha) & $\%$ & (ha) & $\%$ & (ha) & $\%$ & (ha) & $\%$ & \\
\hline 1972 & 9840.3 & 31.5 & - & - & - & - & 1114.8 & 3.4 & 20267.5 & 64.9 & 31222.6 \\
\hline 1991 & 4168.4 & 13.4 & 2201.0 & 7.1 & 1435.8 & 4.6 & 1211.9 & 3.9 & 22205.6 & 71.1 & 31222.6 \\
\hline 2010 & 2760.9 & 8.8 & 2924.4 & 9.4 & 1519.0 & 4.9 & 2146.9 & 6.9 & 21871.4 & 70.1 & 31222.6 \\
\hline 2014 & 2963.3 & 9.5 & 2778.3 & 8.9 & 1537.3 & 4.9 & 259.1 & 0.8 & 23684.6 & 75.9 & 31222.6 \\
\hline
\end{tabular}


occupied the largest proportion of the area throughout the study period, reaching a maximum of 23,684.6 ha in 2014 . Natural forest was the second largest category. It occupied 9,840.3 ha in 1972, declining to 2,760.9 ha in 2010. Rubber and woodlot plantations first appeared in 1991 and gradually increased thereafter. The area of the water bodies peaked (at $2,145.9$ ha) in 2010, and fell dramatically in 2014 .

Accuracy assessment of the classification

Overall classification accuracies and overall kappa statistics obtained for the classified images are listed in Table 5. Kappa coefficient values were aggregated into three groups: (i) values $>80 \%$, representing strong agreement; (ii) values of $40-80 \%$, representing moderate agreement; and (iii) values $<40 \%$, representing poor agreement (Rahman et. al., 2004). The kappa statistics for the year 1972, for example, indicated that our classification system produced a map in which $\geq 97 \%$ of pixels were correctly classified (more than would be expected by random assignment).

Table 5 Accuracy assessment of the classified images

\begin{tabular}{cccc}
\hline $\begin{array}{c}\text { Reference } \\
\text { Year }\end{array}$ & $\begin{array}{c}\text { Classified } \\
\text { image }\end{array}$ & $\begin{array}{c}\text { Overall } \\
\text { classification } \\
\text { accuracy (\%) }\end{array}$ & $\begin{array}{c}\text { Overall kappa } \\
\text { statistics }\end{array}$ \\
\hline 1972 & Landsat MSS & 98.3 & 0.97 \\
1991 & Landsat TM & 86.4 & 0.76 \\
2010 & Landsat TM & 93.2 & 0.89 \\
2014 & Landsat OLI & 91.9 & 0.89 \\
\hline
\end{tabular}

MSS, Multispectral Scanner; TM, Thematic Mapper; OLI, Operational Land Imager

\section{Forest-cover change}

The land-use change statistics for the study area are depicted in Fig. 4. Natural forest cover decreased by $18.2 \%$ from 1972 to 1991 and by $4.5 \%$ from 1991 to 2010 , but increased by $0.7 \%$ from 2010 to 2014 . The absolute and relative changes in natural forest area are summarized in Table 4. In total, 6,877 ha of natural forest cover were lost to other land uses through the study period.

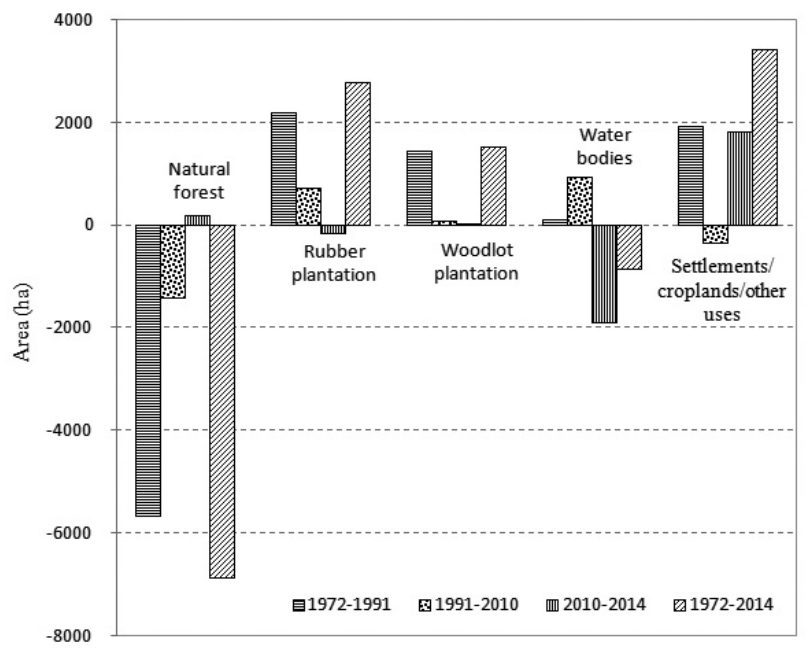

Fig. 4 Land-use change in the periods 1972-1991, 1991-2010, 2010-2014, and 1972-2014
Rubber and woodlot plantation areal changes

The trends in areal occupancy by rubber and woodlot plantations were the reverse of those for natural forest cover. Rubber plantations occurred in the northwestern and southern sectors of the natural forest. Woodlots were located around and within the natural forest. Table 4 summarizes absolute changes in the area occupied by rubber plantations and woodlots through the study period.

Water bodies and settlements/croplands/other uses categories

Most of the water bodies were located in the eastern and western sectors of the natural forest. Their areal extent increased slowly from 1972 to 1991 and more rapidly between 1991 and 2010. Water body area decreased dramatically in 2014 as the areas of natural forest, woodlot plantation, and settlements/croplands/other uses increased. The areas occupied by the settlements/croplands/other uses category were distributed around and within natural forest. Details of areal expansion of this land use category are listed in Table 4.

\section{DISCUSSION}

Trend in forest cover changes

The destruction of natural Sal forest began at the periphery of the stand and moved inward over time. The spatial distribution of damage was variable, with most occurring in northern, northwestern, and southern sectors of the forest. The northwestern sector was clear-cut, and most of the logged tract was converted to a rubber plantation in the period 1972-1991 (Fig. 3b). A heavily deforested area in the southern sector was used as woodlot plantation and possibly for other purposes in the period 1972-1991. Between 1991 and 2010, this area was logged over for rubber tree planting. Commercial monoculture rubber planting was introduced in the Madhupur Sal forest area in 1985 (Gain, 1998). Additional extensive damage was caused in and around the natural forest, likely through human population growth, establishment of settlements, firewood shortages, domestic consumption, poor forest management policies, local-level corruption, land encroachment, illegal felling, conversion of forest land for industrialization, and commercial crop cultivation. Islam and Sato (2012) showed that illegal logging and forest land conversion were the ultimate causes of losses in the Sal forests of Bangladesh. They also indicated that illegal logging is a complex phenomenon promoted by local syndicates; they demonstrated that land conversion to diverse commercial activities directly influenced national policies and prevailing attitudes in the country. Settlements, road networks, and other infrastructure for the burgeoning population in the area had negative impacts on the forest and its wildlife, while continually degrading forest resources. Over the past 20 years, both the human population in the area adjacent to the park and the number of illegal houses inside the forest have doubled; most of the people in this increasing population depend on the forest for their livelihoods (Islam and Sato, 2012). The Forest Department has identified at least 5000 
households in the Madhupur Sal forest area (GOB, 2010). Some of the department's personnel and a few members of the local elite are indirectly responsible for illegal logging in the Sal forests. Corruption in the department has strongly promoted forest conversion (Gain, 2002). Ineffectual and bureaucratic forest management approaches have had immense negative impacts on most state forests in Bangladesh (Ahmed, 2008). The market demand for timber in the overpopulated nation is among the causes contributing to the depletion of forest resources, including losses to illegal logging. People with inadequate incomes covet the wooden furniture seen in television images or in furniture company advertisements (Ahmed, 2008). Additionally, the live firing range of the Bangladesh Air Force (BFA) occupied a significant area (405 ha) after clear cutting began from the southern perimeter of natural forest, causing losses of canopy cover (Gain, 2005).

To reduce the pressure exerted by local forestdependent people on the natural forests and to improve the general understanding of forest resource conservation, Bangladesh has introduced a number of forestry management approaches, including agro-forestry plantations, social or participatory forestry, woodlot plantations, Sal coppice management, and buffer zone management. These approaches may have reduced the rate of deforestation in this area after 1991. Participatory, people-oriented forestry activities have operated in the Tangail forest area since 1987 (Muhammed et al., 2008). The woodlot plantation and agroforestry programs have operated satisfactorily, but the Sal coppice and buffer zone management efforts were total failures (GOB, 2010), and the areas set aside for these projects were occupied by members of the local elite for commercial agriculture enterprises.

Forest cover increased markedly from 2010 through 2014. This is the most optimistic finding of our study. Zaman and Katoh (2011) reported significant increases in forest cover in areas protected by local governments and private owners. They also observed conversion of some croplands into closed forest and open forest tracts in the Thakurgaon forest, located in northern Bangladesh.

A co-management procedure was introduced after 2009 for reforestation by rehabilitation of forest-dependent local and ethnic communities. Conservation measures included the provision of guards, a participatory plantation program in the encroached forest land, and a program to encourage forestdependent people to seek alternative sources of income. The reductions in external pressures probably promoted natural regeneration on the forest floor, which increased canopy cover. Bangladesh government is committed to increase overall forest cover under many forestry management programs which funded by developed countries. In Madhupur Sal forest, the participatory plantation of adjacent and inside encroached land may be added to the natural forest canopy, which also increased overall tree cover. These are the most likely explanations for increases in forest coverage between 2010 and 2014, postulates that are supported by current literature. Revegetation activities have proceeded apace, even as authorities have ignored many of the illegal activities of forest-dependent people and protected their encroachments; despite this inconsistency, the net effect has been a significant improvement in the vegetation (Islam et al., 2013).

\section{Trends in rubber and woodlot plantations}

No rubber or woodlot plantations operated in the Madhupur Sal forest area in 1972. These enterprises began in the 1980s (Fig. 3). Rubber production is an important land-use issue because large tracts of land have been converted from their original natural forest state. At the initiative of the Bangladesh Forest Industries Development Corporation (BFICD), the area under rubber trees increased between 1991 and 2010. Between 2010 and 2014, this area decreased (Table 4), perhaps through encroachment by local people who converted plantations to cropland, mismanagement by authorities charged with plantation protection, or natural calamities. BFIDC (2014) reported that rubber plantations were created in the Madhupur Sal forest in the periods 1987-1989 (2,138.4 ha) and 2001-2002 (1,072.4 ha). Woodlot plantations were established within and around degraded and denuded forest land under the auspices of a reforestation program. This program, which represented an important participatory activity involving local people, was initiated by the Bangladesh Forest Department in 1989 to reduce the anthropogenic pressure on natural forests exerted by the collection of fuel wood, timber, and other resources. GOB (2010) reported that the woodlot plantation enterprise is a dominant operating program among the different participatory management approaches in the Madhupur Sal forest area. Plantation production is a continuous process involving logging and replanting. Spatial and temporal variation in these activities causes variability in the area of land under woodlot cover.

Trends in water body and settlements/croplands/other use categories

The area under water bodies increased slowly through 1991 and then more rapidly until 2010. These changes resulted from continued encroachment into the natural forest. A number of brick kilns built through this period were fired with illegally cut trees. Clay from nearby land was consumed in brick making, and the excavation process may have reduced the topographic elevation. The low-lying tracts contained large volumes of seasonal water in the late rainy and early winter seasons of 2010. On the other hand, as agriculture based country, rice is the major crop in Bangladesh. The only season of high yielding rice production is winter and it starts in January-February. Lot of water as flood irrigation is needed for rice field preparation. Probably, the irrigation water increased the total water volume in 2010 .

Over the entire study period, lands in the settlements/ croplands/other use category occupied the largest area within the park and continued growing through the time span of the study as the natural forest decreased. The area under seasonal water decreased after 2010, leaving open land, whose area peaked in 2014.

The settlements/croplands/other uses and woodlot plantation categories may have been confused in the analysis due to the plantation patterns. A typical rural settlement consisted of native and exotic tree plantations known as 
homestead gardens. In some cases, the homestead garden may have been classified as woodlot plantations. The areas of water bodies may have been overestimated due to mixed pixel effects. The extent of marshland varied among seasons depending on the water regime in the area. Furthermore, the minimum mapping unit size that we used precluded the detection of small changes.

\section{CONCLUSION}

Forest-cover change through deforestation is a major environmental problem in the Bangladeshi Madhupur Sal forest. In this study, we tracked the recent history of forest cover change in the region. Five classes of land use were extracted from satellite images of the park. The extent of forest cover changed markedly between 1972 and 2014, with radical decreases from 1972 to 2010. The areas of forested lands declined by 5,672.0 ha in the period 1972-1991; they fell by 1,407.4 ha in the period 1991-2010. We observed expansions of rubber plantations, woodlot plantations, agricultural lands, and areas in the settlements/croplands/ other use category as the forest cover declined. Across the whole area, 9,840.3 ha of land were covered with forest in 1972, but this value declined to $2,760.9$ ha in 2010. This decrease resulted from anthropogenic changes in the study area, but we did not investigate the activities that led to these changes. Forest coverage dramatically increased from 2010 to 2014, reaching 2,963.3 ha. This increase resulted from co-management practice procedures operated jointly by the Bangladesh Forest Department and local forest-dependent ethnic and non-ethnic peoples.

Therefore, to prevent further destruction of forest resources:

* Local people should be encouraged to plant fast-growing trees within their farm boundaries, on their homesteads, and on degraded lands instead of cutting trees in the existing forest.

* Forest-cover monitoring is required to alert authorities to forest changes; forest maps should be well organized and accurate in location and extent.

* Awareness of the forest conservation system should be promoted among local people by the authorities to support the regeneration of the Sal forest.

\section{ACKNOWLEDGEMENTS}

The authors are grateful to the Madhupur Sal forest office staff for their assistance and active support during information collection. We would like to thank the members of the Forest Measurement and Planning Laboratory, Shinshu University, for their advice and assistance with the study. We sincerely thank Dr. Deng Songqiu for his revisions and corrections to the English in the manuscript. We also express our heartfelt gratitude to Mr. Richard Turner, Textcheck (http://www.textcheck.com/certificate/JPllH0) for his assistance in improving the language of the draft manuscript.

\section{LITERATURE CITED}

Ahmed, A.I.M.U. (2008) Underlying causes of deforestation and forest degradation in Bangladesh. Global forest coalition (GFC), Netherlands. Available from: http://www. globalforestcoalition.org (Accessed on January 10, 2015)

Alam, M., Furukawa, Y., Sarkar, S.K. and Ahmed, R. (2008) Sustainability of Sal (Shorea robusta) forest in Bangladesh: past, present and future actions. Int. Forestry Rev. 10: 29-37

Alam, M., Furukawa, Y. and Harada, K. (2010) Agroforestry as a sustainable land use option in degraded tropical forests: a study from Bangladesh. Environ. Dev. Sustain. 2: 147-158

Alphan, H. (2003) Land use change and urbanization in Adana, Turkey. Land Degrad. Dev. 14: 575-586

BBS (2014) Bangladesh Bureau of Statistics. Statistics \& Informatics Division, Ministry of Planning, Government of the People's Republic of Bangladesh. Available from: http: //www.bbs.gov.bd/ (accessed on April 20, 2015)

BFD (2004) Participatory Forestry Newsletter. Bulletin 3, December 2004. Bangladesh Forestry Department, Government of the People's Republic of Bangladesh.

BFD (2010) Bangladesh Forest Department Homepage, Ministry of Environment and Forest, Government of the People's Republic of Bangladesh. Available from: http:// www.bforest.gov.bd (accessed on October 16, 2014)

BFD (2011) Forest Type: Tropical Moist Deciduous Forests. Bangladesh Forestry Department, Government of the People's Republic of Bangladesh. Available from: http:// bforest. gov. bd / index-category / tropical-moist-dediduousforest (accessed on August 20, 2014)

BFIDC (2014) Bangladesh Forest Industries Development Corporation. Available from: http://bdedure.blogspot.jp/ 2012/06/rubber-plantation-in-bangladesh.html (accessed on October 15, 2014)

Chaurasia, R., Closhali, D.C., Dhaliwal, S.S., Sharma, P.K.M., Kudrat, M. and Tiwari, A.K., (1996) Landuse change analysis for agricultural management: a study of Tehsil Tal-wandi Sabo, Punjap. J. Indian Soc. Remote Sens. 24: 115-123

Feeroz, M.M. and Islam, M.A. (2000) Primates of West Bhanugach Forest Reserve: major threats and management plan. In: Ahmed, M. F. (ed) Bangladesh Environment 2000. BAPA Bangladesh Poribesh Andolon, Maulvibazar. 239-253 pp

FRA (2015) Forest Resources Assessment, country report Bangladesh, 2015. Available from: http://www.fao.org/3/ a-az161e.pdf (Accessed on September 5, 2015)

Gain, P. (2002) The last forests of Bangladesh. Society for Environment and Human Development (SHED), Dhaka, Bangladesh, $224 \mathrm{pp}$

Gain, P. (2005) Bangladesher Biponno Bon. Society for Environment and Human Development (SHED), Dhaka, Bangladesh, $276 \mathrm{pp}$

GLCF (2014) Global Land Cover Facility. Available from: http: //glcf.umd.edu and http://glovis.usgs.gov (accessed on March, 2014) 
GOB (2010) Forest department official website. Government of the People's Republic of Bangladesh, Dhaka, Bangladesh. Available from: http//www.bforest.gov.bd/land.php (accessed on October 20,2014)

Iftekhar, M.S. (2006) Forestry in Bangladesh, an Overview. J. Forest. 104: 148-153

IMF (2005) Bangladesh: Poverty Reduction Strategy Paper. Int. Monitory Fund (IMF) country report No. 05/410. Washington, D.C. $180 \mathrm{pp}$

Islam, J., Ahmed, A.N., Hossain, M.A., Rashid, M.M. and Atauzzaman, M. (2006) Deforestation study of Dinajpur Sal Forest using GIS and remote sensing techniques. J. Subtrop. Agric. Res. Dev. 4: 47-54

Islam, K.K., Rahman, G.M., Fujiwara, T. and Sato, N. (2013) People's participation in forest conservation and livelihoods improvement: experience from a forestry project in Bangladesh. Int. J. Biodiver. Sci. 9: 30-43

Islam, K.K. and Sato, N. (2012) Deforestation, land conversion and illegal logging in Bangladesh: the case of the Sal (Shorea robusta) forests. iForest-Biogeosci. For. 5: 171-178

Islam, S.T. (2006) Resource Assessment of Deciduous Forests in Bangladesh. PhD theses, Durham University. Available at Durham E-theses online: http://etheses.dur.ac.uk/3889/ (Accessed on September 15, 2014)

Lambin, E.F. (1999) Monitoring forest degradation in tropical regions by remote sensing: some methodological issues. Global Ecol. Biogeogr. 8: 191-198

Miller, A.B., Bryant, E.S. and Birnie, R.W. (1998) An analysis of land cover changes in the northern forest of New England using multi-temporal Landsat MSS data. Int. J. Remote Sens. 19 (2): 215-265

Milne, M. (1999) Change direction analysis using imagery: a review of methodology. Proceedings of IGARSS'88 Symposium. Edinburgh, Scotland, 541-544 pp

Muhammed, N., Koike, M., Hauqe, F. and Miah, M.D. (2008) Quantitative assessment of people-oriented forestry in Bangladesh: a case study in the Tangail forest division. J. Environ. Manage. 88: 83-92

Muttitanon, W and Tripathi, N.K. (2005) Land use/cover changes in the coastal zone of Bay Don Bay, Thailand using Landsat 5 TM data. Int. J. Remote Sens. 20:9-20

Naithani, K.K. (1990) Can satellite images replace aerial photographs? A photogrammetrist's view. ITC J. 1: 29-31

Nath, B. (2014) Quantitative assessment of forest cover change of a part of Bandarban Hill tracts using NDVI techniques. J. Geosci. Geomet. 2: 21-27

Quadir, D.A., Rahman, A., Haque, F., Ahmed, I.U. and Runkel, M. (1998) Monitoring of forest cover in Chittagong forest division of Bangladesh using remote sensing and GIS techniques. J. Remote Sens. Environ. 2: 1-18

Rahman, M.M. (2003) Sal forest. In: Islam, S., Miah, S. (eds.) Banglapedia: National Encyclopedia of Bangladesh. Asiatic Society of Bangladesh, Dhaka 9: 28-29

Rahman, M.M., Csaolovics, E., Koch, B. and Kohl, M. (2004) Interpretation of tropical vegetation using Landsat ETM+ Imagery. Available from: http://www.isprs.org/proceedings/ XXXV/congress/yf/papers/951.pdf (Accessed on August $16,2015)$

Rasheed, K. B.S. (2008) Bangladesh-Resource and Environmental Profile. A H Development Publishing House. Dhaka, 103 pp

Rosenholm, D. (1993) Land use and vegetation cover mapping by satellite: SSC Satellite experiences. ITC J. 3: 251-260

Salam, M.A. and Noguchi, T. (2006) Evaluating capacity development for participatory forest management in Bangladesh Sal forests based on stakeholder analysis. For. Policy Econo. 8: 785-796

UNEP (2002) Bangladesh State of the Environment 2001. United Nations Environment Programme, Regional Resource Centre for Asia and the Pacific (UNEP RRCAP), Pathumthani 12120. Thailand, $17 \mathrm{pp}$

USGS (2014) U.S. Geological Survey-Band Designations for the Landsat Satellites. Available from: http://landsat.usgs. gov/best_spectral_bands_to_use.php. (Accessed on March 20, 2014)

Webb, E.L. and Sah, R.N. (2003) Structure and diversity of natural and managed Sal (Shorea robusta) forest in the Terai of Nepal. For. Ecol. Manage. 176: 337-353

Zaman, S. and Katoh, M. (2011) Assessment of forest covers change in tropical moist deciduous forest in Thakurgaon, Bangladesh using ALOS data. Jpn. J. For. Soc. 16: 285-292

(Received 19 March 2015)

(Accepted 21 January 2016) 